\title{
Integration of Composts with NPK Improved Soil Fertility, Growth and Yield of Sorghum in Sandy Desert Soils of Sudan
}

\author{
Abdelraheim Mohamed Said Ahmed ${ }^{1}$, Majed Abu-Zreig ${ }^{2,4}$, Mubarak Abdelrahman Abdalla ${ }^{3 *}$, Norikazu Yamanaka ${ }^{4}$, \\ Elsadig Agabna Elhadi ${ }^{5}$ and Fatoma Ali Mohammed Rezig ${ }^{6}$ \\ ${ }^{1}$ Department of Soil and Water Sciences, Faculty of Natural Resources and Environmental Sciences, University of Kordofan, \\ Sudan \\ ${ }^{2}$ Civil Engineering Department, Jordan University of Science and Technology, Irbid, Jordan \\ ${ }^{3}$ Desertification and Desert Cultivation Studies Institute, University of Khartoum, Sudan \\ ${ }^{4}$ Arid Land Research Center, IPDRE, Tottori University, 1390 Hamasaka, Tottori-shi, 6800-0001, Japan \\ ${ }^{5}$ Institute of Environmental Studies, University of Khartoum, Sudan \\ ${ }^{6}$ Environment, Natural Resources and Desertification Research Institute, National Research Center for Research, Khartoum, \\ Sudan \\ *For correspondence: mubarakgeziraaba@gmail.com; majed@just.edu.jo \\ Received 30 August 2019; Accepted 18 September 2019; Published 16 January 2020
}

\begin{abstract}
Sandy desert soil in Sudan are characterised by low content of organic matter, small water holding capacity and low crop productivity. Methods to enhance crop productivity on these environments, such as land application of composts, are of great importance. Field experiments were conducted on a sandy soil to determine the effects of two types of composted manures on growth and yield of two sorghum varieties grown under rainfed conditions. Two sorghum cultivars (Butana and Arfa Gadmak were sown under chicken manure (CM) compost $\left(5 \mathrm{t} \mathrm{ha}^{-1}\right), \mathrm{CM}$ compost with NPK $\left(36 \mathrm{~kg} \mathrm{ha}^{-1}\right)$, farm manure (FM) compost $\left(20 \mathrm{t} \mathrm{ha}^{-1}\right)$, FM compost with NPK $\left(36 \mathrm{~kg} \mathrm{ha}^{-1}\right), \mathrm{CM}$ compost with FM compost $\left(1: 1, \mathrm{wt} / \mathrm{wt}, 12.5 \mathrm{t} \mathrm{ha}^{-1}\right), \mathrm{CM}$ and FM composts with NPK (36 kg ha $\left.{ }^{-1}\right)$, only NPK (36 kg ha ${ }^{-1}$ ) and control (no composts or NPK). Application of composts increased organic soil carbon by $50 \%$ and available phosphorous $(\mathrm{P})$ between 43 to $105 \%$, whereas, $\mathrm{pH}$ and bulk density were decreased by 2 and 6\%, respectively. Soil moisture contents in compost treated plots were 56-98\% higher than control plots. Mixing compost with NPK increased leaf area index over NPK alone by $28 \%$ but the highest values were found in plots treated with chicken compost or integrated with NPK compared to NPK application alone. Incorporation of compost increased dry matter yield compared to control by $17-53 \%$ and increased grain yield by 1.8 to 3.1 fold in both sorghum varieties. Grain yield from plots treated with NPK, sole chicken compost or combined with NPK were similar for both varieties in both seasons. In general, the trend of grain yield of sorghum was in the order of NPK = chicken compost with NPK = chicken compost $=$ farm manure compost with NPK $>$ mixed compost with NPK = farm manure > control. In conclusion, integrating composts with NPK improved fertility of sandy soils, sorghum growth and yield. (C) 2020 Friends Science Publishers
\end{abstract}

Keywords: Compost; Drylands; Organic amendment; Soil fertility; Yield

\section{Introduction}

Sorghum [Sorghum bicolor (L.) Moench] is globally ranked as the fifth cereal crop after wheat, maize, rice and barley and is one of the most important staple food and fodder crops in the semi - arid region of the world (FAO 2009). Sorghum follows the $\mathrm{C}_{4}$ photosynthesis where stomatal transpiration is greatly reduced by the efficient uptake of $\mathrm{CO}_{2}$ and therefore the crop is characterized by high tolerance to drought and heat stress (Kakani et al. 2011; Ogbaga et al. 2014). In Sudan, around 3.7 million tons of grain sorghum is annually produced from 9.1 million hectares (FAO 2018) compared to global 63.5 million tons
(Mundia et al. 2019). The United States of America, Nigeria, India, Mexico and Sudan dominate world sorghum production. However, sorghum production in these countries varied from $4.66 \mathrm{t} \mathrm{ha}^{-1}$ to as low as $0.75 \mathrm{t} \mathrm{ha}^{-1}$ in Sudan. Poor soil quality and performance of cultivated genotypes, fluctuation of rainfall and poor implementation of recommended cultural practices are the main reasons behind low sorghum productivity.

Sandy soils are widely spread in the southern and eastern parts of Africa covering about $13 \%$ of the land. These soils have greater than $70 \%$ sand and less than $15 \%$ clay and therefore, classified as Arenosols in the World References Base (FAO 2001). These soils have weak

To cite this paper: Ahmed AMS, M Abu-Zreig, MA Abdalla, N Yamanaka, EA Elhadi, FAM Rezig (2020). Integration of composts with NPK improved soil fertility, growth and yield of sorghum on sandy desert soils in Sudan. Intl J Agric Biol 23:373-380 
developed horizon formation, with high water permeability, low water - holding capacity and often-low nutrient contents (Chesworth 2008). There is increasing interest in utilizing sandy soils of low or marginal productivity for crop production to match the rising demand of food worldwide (e.g., Rezig et al. 2013; Asomaning et al. 2015).

In western Sudan, traditional rainfed farming in sandy soils is the major production system and contributes significantly to the production of important cash crops. Improvements of in the cultivation practices such as seed priming and micro dosing of fertilizer have increased crop establishment, yields and net return (Osman et al. 2012). Therefore, enhancing cultivation practices with land application of organic byproducts, such as manure, is highly important in the drylands of Sudan and the sub-Saharan Africa.

Worldwide increase in area under cultivation in irrigated agriculture has been long achieved with addition of fertilizers, i.e., NPK. However, researchers reported a considerable encouragement for using organic manures in irrigated sandy soils (Ozores-Hampton et al. 2011; Mubarak and Ballah 2015; Rehim et al. 2016). The North Kordofan State enjoys considerable number of livestock including chicken, sheep, goats, camels and cattle that represented about $37 \%$ of Sudan's animal resources. The estimated daily compost production from cattle manure is about 600 to 1000 ton day $^{-1}$, despite that, the use of composts for crop production in the area is rather limited. Researches on the land application of combined manure with NPK and its effect on crop production is even scarcer. Therefore, the aim of this study was to investigate the influence of two types of animal's manure composts with and without addition of NPK on the properties of sandy soil and production of sorghum under rainfed conditions.

\section{Materials and Methods}

\section{Study site}

A field experiment was conducted for two successive rainfed seasons (2013 and 2014), in the Experimental Research Farm, Department of Soil and Water Sciences, Faculty of Natural Resources and Environmental Studies, University of Kordofan, Elobeid, North Kordofan State $\left(12^{\circ}\right.$ $00^{\prime \prime}$ and $16^{\circ} 16^{\prime \prime} \mathrm{N}$ and $26^{\circ} 15^{\prime \prime}$ and $30^{\circ} 30^{\prime \prime} \mathrm{E}$ with $750 \mathrm{~m}$ above sea level). The climatic zone ranges from arid and semiarid in the north to wet in the extreme south. The soil is sandy and classified according to the F.A.O. terminology as cambric Arenosols (Table 1). These are coarse-textured soils of Aeolian origin, locally known as Qoz (Warren 1970). Mean ranges of daily maximum and minimum temperatures are $32-35^{\circ} \mathrm{C}$ and $17-21^{\circ} \mathrm{C}$, respectively whereas annual rainfall ranges between 350 and $500 \mathrm{~mm}$ (Fig. 1). The two seasons (2013 and 2014) differed greatly in their environmental conditions notably the amount and distribution of rainfall. The sec season (2014) had high and favorable rainfall distributed of $228.5 \mathrm{~mm}$ compared to only $113.5 \mathrm{~mm}$ in 2013. The 2013 season showed also poor monthly distribution of rainfall and notably low rainfall in July of only $11.4 \mathrm{~mm}$ (Fig. 1) that had significant effects on the growth of sorghum as will be shown in the section of results.

\section{Compost preparation}

Farm manure (FM) was collected from Khor-Taggat Village east El-Obeid where livestock graze on opened filed vegetation, whereas, chicken manure (CM) was collected from Draggas Farm, Elkhor Elabiad, south Elobied. The initial characters of FM and CM are presented in Table 2. Composts were prepared from sole FM or CM or mixture of FM and CM at a ratio of $1: 1$ by weight and piled in a volume of $2 \mathrm{~m}^{3}(2 \mathrm{~m} \times 1 \mathrm{~m} \times 1 \mathrm{~m})$. The feedstock was formed as a heap $\left(2 \mathrm{~m}^{3}\right)$ following the Indian Indore Heap Method (FAO 1980) for a period of 12 weeks. The moisture content was kept at 70-75\% of water holding capacity by regular water spraying. After 12 weeks, triple samples from each compost were taken, air dried, ground sieved $(0.5 \mathrm{~mm})$ and characterized for $\mathrm{pH}_{(1: 5)}$ (Mclean 1982), total $\mathrm{N}$ (Nelson and Sommers, 1982) and $\mathrm{P}, \mathrm{K}^{+}, \mathrm{Na}^{+}, \mathrm{Ca}^{2+}, \mathrm{Mg}^{2+}$ (AOAC 1984) and organic C (Walkley and Black 1934).

In general, the final compost has lower $\mathrm{TN}, \mathrm{Mg}^{2+}, \mathrm{P}$, $\mathrm{OC}$, lignin, cellulose and hemicellulose values compared to initial one. The large decrease was found for the $\mathrm{P}$ content with an average decrease of $92 \%$ for the combined three types of composts. However, manure composting prepared from FM, CM and FM/CM significantly increased $\mathrm{Ca}^{2+}$ by an average of $63 \%$ and $\mathrm{C} / \mathrm{N}$ ratio compared to initial feedstock by 52,53 and $70 \%$, respectively. Organic C, lignin, cellulose and hemicellulose of the final composts were reduced by an average of 12, 43, 22 and 10\%, respectively. The final compost prepared from $\mathrm{CM}$ has lowest OC (146 g kg$\left.{ }^{-1}\right), \mathrm{C} / \mathrm{N}$ (18.1) and hemicellulose (82 g $\mathrm{kg}^{-1}$ ), whereas the FM compost had the highest values of 266, 365 and 265, respectively. Mixing CM with FM resulted in a decrease in the $\mathrm{OC}, \mathrm{C} / \mathrm{N}$ and hemicellulose by 17,23 and $57 \%$, respectively while increased $\mathrm{TN}, \mathrm{Mg}^{2+}$ and $\mathrm{Ca}^{2+}$ contents by $14-19 \%$.

\section{Experimental protocol}

Seven types of treatments in four replicates were prepared and applied on field plots, two weeks before the start of the rainy season. Two sorghum varieties i.e., Butana and Arfa Gadmak were sown using CM compost $\left(5 \mathrm{t} \mathrm{ha}^{-1}\right)$, CM compost with NPK (36 kg ha $\left.{ }^{-1}\right)$, FM compost $\left(20 \mathrm{t} \mathrm{ha}^{-1}\right)$, FM compost with NPK (36 kg ha $\left.{ }^{-1}\right)$, CM compost and FM compost $\left(1: 1\right.$, wt/wt, $\left.12.5 \mathrm{t} \mathrm{ha}^{-1}\right), \mathrm{CM}$ compost and FM compost with NPK (36 kg ha-1), only NPK (36 kg ha') and control (no composts or NPK). Treatments with four replicates were arranged in a split plots design with varieties assigned to the main plots and compost to the sub-plots. Composts were manually incorporated into the top $30 \mathrm{~cm}$ 
Influence of Compost on Sorghum Growth in Desert Soils / Intl J Agric Biol, Vol 23, No 2, 2020

Table 1: Some selected initial physico-chemical properties of the top $0-30 \mathrm{~cm}$ soil depth in the study site

\begin{tabular}{|c|c|c|c|c|c|c|c|c|c|c|c|}
\hline \multirow[t]{2}{*}{ Property } & \multirow[t]{2}{*}{$\mathrm{pH}_{\text {(paste) }}$} & EC & $\mathrm{OC}$ & $\mathrm{TN}$ & $\mathrm{P}$ & $\mathrm{K}$ & \multirow[t]{2}{*}{$\mathrm{Bd} \mathrm{g} \mathrm{cm}^{3}$} & WHC & Sand & Silt & Clay \\
\hline & & $\mathrm{dS} \mathrm{m}^{-1}$ & $\mathrm{~g} \mathrm{~kg}^{-1}$ & & $\mathrm{~g} \mathrm{~kg}^{-1}$ & & & $(\%)$ & & & \\
\hline & 6.65 & 0.16 & 1.6 & 0.1 & 2.62 & 2.77 & 1.44 & 31.6 & 90.14 & 7.22 & 2.64 \\
\hline
\end{tabular}

EC: Electrical Conductivity, OC: Organic Carbon, TN: Total Nitrogen, P: Phosphorous, K: Potassium, Bd: Bulk density, WHC: Water Holding Capacity

Table 2: Some selected initial properties of the compost (average \pm standard deviation)

\begin{tabular}{|c|c|c|c|c|c|c|c|c|c|c|}
\hline \multirow[t]{2}{*}{ Manure Feedstock } & \multirow[t]{2}{*}{$\mathrm{pH}_{(1: 5)}$} & $\mathrm{OC}$ & $\mathrm{TN}$ & $\mathrm{Ca}^{2+}$ & $\mathrm{Mg}^{2+}$ & $\mathrm{P}$ & Lignin & Cellulose & Hemicellulose & $\mathrm{C} / \mathrm{N}$ \\
\hline & & \multicolumn{9}{|c|}{$\mathrm{g} \mathrm{kg}^{-1}$} \\
\hline$\overline{\text { FM }}$ & $7.33 \pm 0.01$ & $310.3 \pm 2.3$ & $13.0 \pm 0.01$ & $1.9 \pm 0.01$ & $3.9 \pm 0.01$ & $15.7 \pm 0.03$ & $226.3 \pm 0.03$ & $192.0 \pm 0.40$ & $265.4 \pm 0.80$ & 23.9 \\
\hline $\mathrm{CM}$ & $6.88 \pm 0.01$ & $177.3 \pm 2.3$ & $15.0 \pm 0.02$ & $1.9 \pm 0.02$ & $6.9 \pm 0.03$ & $16.1 \pm 0.05$ & $170.0 \pm 0.14$ & $324.0 \pm 0.05$ & $109.0 \pm 0.16$ & 11.8 \\
\hline $\mathrm{FM} / \mathrm{CM}$ & $6.94 \pm 0.03$ & $237.0 \pm 2.3$ & $14.4 \pm 0.01$ & $1.7 \pm 0.02$ & $5.0 \pm 0.01$ & $14.0 \pm 0.02$ & $188.0 \pm 0.05$ & $247.0 \pm 0.30$ & $158.0 \pm 0.06$ & 16.5 \\
\hline
\end{tabular}

FM: farm yard manure, CM: Chicken manure; OC: Organic carbon, TN: total Nitrogen, P: Phosphorous, C/N: Carbon/Nitrogen ratio; Ca: Calcium, Mg: Magnesium

Table 3: Final some selected properties of the composts used in the experiment (Average \pm standard deviation, $n=4$ )

\begin{tabular}{|c|c|c|c|c|c|c|}
\hline Property & FM & $\mathrm{CM}$ & FM/CM & Probability & $\mathrm{CV}$ & LSD \\
\hline $\mathrm{pH}_{(1: 5)}$ & $8.6 \pm 0.20$ & $8.7 \pm 0.04$ & $8.2 \pm 0.03$ & $\leq 0.01$ & 1.6 & 0.26 \\
\hline $\mathrm{OC}\left(\mathrm{g} \mathrm{kg}^{-1}\right)$ & $266.0 \pm 1.7$ & $146.0 \pm 0.02$ & $227 \pm 0.04$ & $\leq 0.01$ & 4.6 & 1.96 \\
\hline $\mathrm{TN}\left(\mathrm{g} \mathrm{kg}^{-1}\right)$ & $7.10 \pm 0.07$ & $8.10 \pm 0.02$ & $8.1 \pm 0.01$ & $\leq 0.05$ & 5.5 & 0.09 \\
\hline $\mathrm{C} / \mathrm{N}$ & $36.4 \pm 2.4$ & $18.1 \pm 0.44$ & $28.0 \pm 0.35$ & & & \\
\hline $\operatorname{Mg}^{++}\left(\mathrm{g} \mathrm{kg}^{-1}\right)$ & $2.9 \pm 0.02$ & $6.5 \pm 0.02$ & $3.4 \pm 0.02$ & $\leq 0.01$ & 4.8 & 0.04 \\
\hline $\mathrm{Ca}^{++}\left(\mathrm{g} \mathrm{kg}^{-1}\right)$ & $2.6 \pm 0.02$ & $3.3 \pm 0.03$ & $3.1 \pm 0.02$ & $\leq 0.05$ & 7.8 & 0.05 \\
\hline $\mathrm{K}^{+}\left(\mathrm{g} \mathrm{kg}^{-1}\right)$ & $2.9 \pm 0.03$ & $3.5 \pm 0.05$ & $2.7 \pm 0.07$ & $\leq 0.01$ & 5.2 & 2.85 \\
\hline $\mathrm{P}\left(\mathrm{mg} \mathrm{kg}^{-1}\right)$ & $1.3 \pm 0.03$ & $1.2 \pm 0.03$ & $1.2 \pm 0.02$ & $\leq 0.01$ & 2.1 & 0.53 \\
\hline $\operatorname{Lignin}\left(\mathrm{g} \mathrm{kg}^{-1}\right)$ & $81.1 \pm 0.03$ & $121.0 \pm 0.03$ & $128.0 \pm 0.05$ & $\leq 0.01$ & 0.3 & 0.07 \\
\hline Cellulose $\left(\mathrm{g} \mathrm{kg}^{-1}\right)$ & $165.8 \pm 0.4$ & $247.0 \pm 0.5$ & $185.3 \pm 0.4$ & $\leq 0.01$ & 1.6 & 0.64 \\
\hline Hemicellulose $\left(\mathrm{g} \mathrm{kg}^{-1}\right)$ & $247.3 \pm 0.6$ & $081.9 \pm 0.2$ & $113.5 \pm 0.3$ & $\leq 0.01$ & 3.2 & 0.97 \\
\hline
\end{tabular}

FM: Farm Yard Manure, CM: Chicken Manure, CV: Coefficient of Variability, LSD: Least Significant Difference; OC: Organic carbon, TN: total Nitrogen, P: Phosphorous, C/N: Carbon/Nitrogen ration

depth of plots $(3 \mathrm{~m} \times 2 \mathrm{~m})$ using locally manufactured forks.

Sorghum was manually sown at $0.5 \mathrm{~m}$ spacing between and within rows. Sorghum was sown on 27/06/2013 for the 2013-2014 season and on 01/07/2014 for the 2014-2015 season. Weeding was carried out manually after 15 days from sowing and whenever needed to keep plots free from weeds. After one week from sowing, plants were thinned to three plants per hole.

At harvest (mid of October in both season), ten plants were randomly selected from the two inner rows for measurements of stem diameter $(\varnothing \mathrm{cm})$, plant height $(\mathrm{H}$, $\mathrm{cm})$, number of leaves $\left(\mathrm{NL}_{\text {plant }}{ }^{-1}\right)$, leaf area (LA), leaf area index (LAI), number of seeds plant ${ }^{-1}$ (NS/P), seed weight per panicle (SW/P), $100 \mathrm{~g}$ seed weight $(\mathrm{SW})$ and moisture content of straw. Plots were manually harvested, grain and straw dry matter yield (DM) were determined in $\mathrm{t} \mathrm{ha}^{-1}$. The significance of treatments and the difference among the treatment's means were analyzed first with ANOVA then using Tuckey HSD multiple range test, respectively using S.A.S. package system (SAS 1999).

\section{Results}

Effects of compost application on performance of sorghum

Application of compost on crop performance, yield and yield components showed significant effect in both seasons

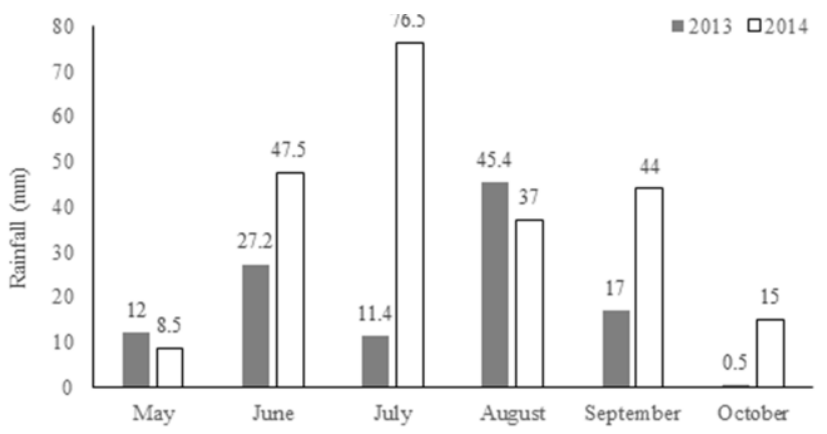

Fig. 1: Rainfall (mm) during the growing seasons of 2013 and 2014

(Table 4 and 5). In general, the chicken manure compost (CM) followed by farm yard manure (FM) treatment had had significant increases on the grain yield parameters including grain yield, $100 \mathrm{~g}$ seed weight, seed weight per Panicle, Number of seeds per Panicle of sorghum compared to the control. However, FM seemed to improve the vegetative growth of sorghum significantly compared to control treatment more than CM treatment, i.e., stem diameter, stem height, number of leaves per plant, leaf area and dry matter yield, as shown in Table 4. In both cases the differences between FM and CM were not significant. The treatment composed of FM/CM mix, seemed to have the lowest influence on sorghum yield and vegetated growth compared to all other treatments. In the sec season 2014, 
Table 4: Effects of organic composts and NPK application alone and in combinations on yield and related traits of sorghum during 20132014 (Average \pm standard deviation, $n=4$ )

\begin{tabular}{|c|c|c|c|c|c|c|c|c|c|c|}
\hline Treatments & $\varnothing \mathrm{cm}$ & $\mathrm{H} \mathrm{cm}$ & NL/PT & LA & LAI & $\mathrm{NS} / \mathrm{P}$ & $\overline{\mathrm{SW} / \mathrm{P}}$ & $100 \mathrm{gSW}$ & DMY & GY \\
\hline \multicolumn{11}{|c|}{ Butana } \\
\hline $\mathrm{T}_{0}$ & $0.8 \mathrm{a} \pm 0.0$ & $36 a \pm 5$ & $6.4 a \pm 0.9$ & $102 b \pm 18$ & $0.45 b c \pm 0.2$ & $223 c \pm 49$ & $3.2 \mathrm{c} \pm 0.4$ & $1.9 \mathrm{e} \pm 0.2$ & $1.95 \mathrm{~cd} \pm 0.5$ & $0.25 c \pm 0.1$ \\
\hline $\mathrm{T}_{1}$ & $0.8 \mathrm{a} \pm 0.1$ & $37 a \pm 6$ & $6.0 \mathrm{a} \pm 1.0$ & $102 b \pm 43$ & $0.46 b c=0.2$ & $262 b c \pm 13$ & $5.3 b \pm 0.3$ & $2.4 \mathrm{abc} \pm 0.3$ & $2.13 \mathrm{bcd} \pm 0.5$ & $0.40 \mathrm{~b} \pm 0.0$ \\
\hline $\mathrm{T}_{2}$ & $1.2 \mathrm{a} \pm 0.3$ & $50 \mathrm{a} \pm 1$ & $6.0 \mathrm{a} \pm 1.0$ & $189 a \pm 78$ & $0.70 \mathrm{a} \pm 0.2^{*}$ & $292 b \pm 61$ & $8.4 a \pm 0.7$ & $2.1 \mathrm{ed} \pm 0.4$ & $2.70 \mathrm{ab} \pm 0.7$ & $0.70 \mathrm{a} \pm 0.1$ \\
\hline $\mathrm{T}_{3}$ & $0.9 \mathrm{a} \pm 0.2$ & $41 \mathrm{a} \pm 9$ & $5.5 \mathrm{a} \pm 0.8$ & $107 b \pm 41$ & $0.70 \mathrm{a} \pm 0.3$ & $362 \mathrm{a} \pm 27$ & $8.7 \mathrm{a} \pm 0.2$ & $2.7 \mathrm{a} \pm 0.2$ & $2.63 \mathrm{abc} \pm 0.3$ & $0.75 a \pm 0.1$ \\
\hline $\mathrm{T}_{4}$ & $1.1 \mathrm{a} \pm 0.1$ & $49 a \pm 3$ & $5.7 \mathrm{a} \pm 1.2$ & $163 a \pm 40$ & $0.48 b c \pm 0.1$ & $347 a \pm 23$ & $8.2 \mathrm{a} \pm 0.2$ & $2.3 b c d \pm 0.1$ & $2.56 \mathrm{abc} \pm 0.6$ & $0.65 a \pm 0.1$ \\
\hline $\mathrm{T}_{5}$ & $0.9 \mathrm{a} \pm 0.1$ & $45 \mathrm{a} \pm 4$ & $5.3 a \pm 0.9$ & $100 b \pm 42$ & $0.36 \mathrm{c} \pm 0.2$ & $339 a \pm 26$ & $8.1 \mathrm{a} \pm 0.9$ & $2.5 \mathrm{ab} \pm 0.2$ & $1.70 \mathrm{~d} \pm 0.2$ & $0.65 \mathrm{a} \pm 0.1$ \\
\hline \multicolumn{11}{|c|}{ Arfa Gadmak } \\
\hline $\mathrm{T}_{0}$ & $1.0 \mathrm{a} \pm 0.2$ & $33 a \pm 4$ & $6.4 \mathrm{a} \pm 0.9$ & $102 \mathrm{a} \pm 17$ & $0.33 \mathrm{a} \pm 0.2$ & $223 c=20$ & $4.1 \mathrm{~d} \pm 0.3$ & $1.9 \mathrm{~d} \pm 0.2$ & $2.60 b c \pm 0.7$ & $0.33 \mathrm{~d} \pm 0.1$ \\
\hline $\mathrm{T}_{1}$ & $1.0 \mathrm{a} \pm 0.1$ & $36 \mathrm{a} \pm 2$ & $6.0 \mathrm{a} \pm 1.0$ & $97 \mathrm{a} \pm 17$ & $0.60 \mathrm{a} \pm 0.2$ & $293 b \pm 19$ & $6.3 b \pm 0.4$ & $2.4 \mathrm{ab} \pm 0.3$ & $2.47 b c \pm 0.2$ & $0.50 \mathrm{~b} \pm 0.0$ \\
\hline $\mathrm{T}_{2}$ & $0.9 \mathrm{a} \pm 0.2$ & $33 \mathrm{a} \pm 2$ & $6.0 \mathrm{a} \pm 0.9$ & $105 a \pm 23$ & $0.50 \mathrm{ac} \pm 0.2$ & $297 b \pm 16$ & $6.3 b \pm 0.3$ & $2.2 b c \pm 0.2$ & $2.09 \mathrm{c} \pm 0.8$ & $0.50 \mathrm{~b} \pm 0.0$ \\
\hline $\mathrm{T}_{3}$ & $1.0 \mathrm{a} \pm 0.1$ & $36 \mathrm{a} \pm 4$ & $5.5 \mathrm{a} \pm 0.8$ & $108 \mathrm{a} \pm 45$ & $0.55 \mathrm{a} \pm 0.2$ & $348 \mathrm{a} \pm 11$ & $8.3 \mathrm{a} \pm 0.5$ & $2.6 \mathrm{a} \pm 0.1$ & $2.13 c \pm 0.3$ & $0.65 \mathrm{a} \pm 0.1$ \\
\hline $\mathrm{T}_{4}$ & $1.1 \mathrm{a} \pm 0.1$ & $38 a \pm 3^{*}$ & $5.7 \mathrm{a} \pm 1.2$ & $127 \mathrm{a} \pm 25$ & $0.43 a \pm 0.2$ & $347 \mathrm{a} \pm 28$ & $7.8 \mathrm{a} \pm 0.2$ & $2.3 b c \pm 0.1$ & $2.48 b c \pm 0.3$ & $0.60 \mathrm{a} \pm 0.0$ \\
\hline $\mathrm{T}_{5}$ & $1.1 \mathrm{a} \pm 0.0$ & $36 \mathrm{a} \pm 4$ & $5.3 \mathrm{a} \pm 0.9$ & $100 \mathrm{a} \pm 09$ & $0.33 a \pm 0.1$ & $309 b \pm 10$ & $7.7 \mathrm{a} \pm 0.6$ & $2.5 \mathrm{a} \pm 0.2$ & $3.01 \mathrm{ab} \pm 0.5$ & $0.60 \mathrm{a} \pm 0.1$ \\
\hline $\mathrm{T}_{7}$ & $1.0 \mathrm{a} \pm 0.1$ & $36 a \pm 6$ & $5.3 \mathrm{a} \pm 1.0$ & $110 \mathrm{a} \pm 22$ & $0.50 \mathrm{ac} \pm 0.1$ & $243 c \pm 29$ & $5.5 c \pm 0.3$ & $2.6 \mathrm{a} \pm 0.1$ & $2.48 b c \pm 0.5$ & $0.45 b \mathrm{c} \pm 0.1$ \\
\hline
\end{tabular}

$\varnothing$ : Stem diameter (mm), H: Stem height (cm), NL/PT: Number of leaves per plant, LA: Leaf area $\left(\mathrm{cm}^{2}\right)$, LAI: Leaf area index, NS/P: Number of seeds per panicle, SW/P: Seed weight per panicle (g), 100gSW: 100-seed weight (g), DMY: Dry matter yield $\left(\mathrm{t} \mathrm{ha}^{-1}\right)$, GY: Grain yield $\left(\mathrm{t} \mathrm{ha}^{-1}\right)$

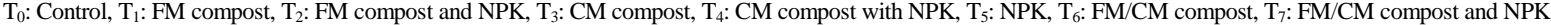

Values in columns for each variety (Butana and Arfa Gadmak) followed by different letter (s) are significantly different at $P \leq 0.05$

Table 5: Effects of organic composts and NPK application alone and in combinations on yield and related traits of sorghum during 20142015 (Average \pm standard deviation, $n=4$ )

\begin{tabular}{|c|c|c|c|c|c|c|c|c|c|c|}
\hline Treatments & $\varnothing \mathrm{cm}$ & $\mathrm{H} \mathrm{cm}$ & NL/PT & LA & LAI & $\mathrm{NS} / \mathrm{P}$ & $\mathrm{SW} / \mathrm{P}$ & $100 \mathrm{gSW}$ & DMY & GY \\
\hline \multicolumn{11}{|c|}{ Butana } \\
\hline $\mathrm{T}_{0}$ & $1.3 \mathrm{a} \pm 0.1$ & $74 a \pm 11$ & $4.8 \mathrm{a} \pm 1.4$ & $164 \mathrm{~cd} \pm 30$ & $0.70 \mathrm{c} \pm 0.1$ & $636 \mathrm{e} \pm 28$ & $07.2 \mathrm{e} \pm 0.4$ & $1.2 \mathrm{~d} \pm 0.1$ & $2.71 c \pm 0.9$ & $0.58 \mathrm{e} \pm 0.1$ \\
\hline $\mathrm{T}_{1}$ & $1.3 \mathrm{a} \pm 0.0$ & $76 a \pm 7$ & $4.7 \mathrm{a} \pm 0.7$ & $204 a b c \pm 19$ & $0.90 b c \pm 0.2$ & $1109 \mathrm{~d} \pm 46$ & $14.1 \mathrm{~d} \pm 1.5$ & $1.4 \mathrm{c} \pm 0.1$ & $3.25 b \pm 0.3$ & $1.13 \mathrm{~d} \pm 0.1$ \\
\hline $\mathrm{T}_{2}$ & $1.3 \mathrm{a} \pm 0.1$ & $90 \mathrm{a} \pm 9$ & $4.6 \mathrm{a} \pm 0.5$ & $182 \mathrm{bcd} \pm 47$ & $1.14 b \pm 0.2$ & $1247 \mathrm{c} \pm 115$ & $16.7 \mathrm{c} \pm 1.4$ & $1.4 \mathrm{c} \pm 0.1$ & $3.32 \mathrm{~b} \pm 0.8$ & $1.33 c \pm 0.1$ \\
\hline $\mathrm{T}_{3}$ & $1.3 \mathrm{a} \pm 0.1$ & $99 a \pm 6$ & $5.1 \mathrm{a} \pm 0.5$ & $241 \mathrm{a} \pm 32$ & $0.97 b c \pm 0.2$ & $1329 b c \pm 32$ & $20.5 b \pm 0.9$ & $1.7 \mathrm{~b} \pm 0.1$ & $3.16 b \pm 0.4$ & $1.65 b \pm 0.1$ \\
\hline $\mathrm{T}_{4}$ & $1.4 \mathrm{a} \pm 0.1$ & $85 a \pm 6$ & $4.5 \mathrm{a} \pm 0.9$ & $209 a b c \pm 15$ & $1.48 \mathrm{a} \pm 0.3$ & $1353 b \pm 17$ & $22.3 b \pm 2.6$ & $1.7 \mathrm{~b} \pm 0.1$ & $3.43 b \pm 0.6$ & $1.80 \mathrm{~b} \pm 0.2$ \\
\hline $\mathrm{T}_{5}$ & $1.3 \mathrm{a} \pm 0.1$ & $85 a \pm 4$ & $4.6 \mathrm{a} \pm 0.3$ & $137 d \pm 22$ & $1.11 b \pm 0.2$ & $1674 a \pm 93$ & $30.5 a \pm 2.4$ & $1.7 \mathrm{~b} \pm 0.1$ & $4.09 \mathrm{a} \pm 0.7$ & $2.45 \mathrm{a} \pm 0.2$ \\
\hline $\mathrm{T}_{6}$ & $1.3 \mathrm{a} \pm 0.0$ & $85 a \pm 8$ & $5.7 \mathrm{a} \pm 0.9$ & $226 a b \pm 60$ & $0.75 \mathrm{c} \pm 0.1$ & $1124 d \pm 54$ & $16.3 \mathrm{~cd} \pm 0.9$ & $1.5 \mathrm{c} \pm 0.1$ & $3.68 b \pm 1.4$ & $1.30 \mathrm{~cd} \pm 0.1$ \\
\hline $\mathrm{T}_{7}$ & $1.2 \mathrm{a} \pm 0.1$ & $62 \mathrm{a} \pm 8$ & $5.0 \mathrm{a} \pm 0.9$ & $134 d \pm 16$ & $1.55 \mathrm{a} \pm 0.2$ & $1304 b c \pm 80$ & $20.3 b \pm 1.5$ & $1.9 \mathrm{a} \pm 0.2$ & $3.90 \mathrm{a} \pm 0.8$ & $1.63 b \pm 0.1$ \\
\hline \multicolumn{11}{|c|}{ Arfa Gadmak } \\
\hline $\mathrm{T}_{0}$ & $1.5 \mathrm{c} \pm 0.2$ & $74 a \pm 2$ & $6 . \mathrm{a} 1 \pm 0.6$ & $179 a \pm 37$ & $1.07 \mathrm{a} \pm 0.4$ & $512 d \pm 47$ & $09.6 \mathrm{~d} \pm 0.7$ & $2.2 \mathrm{a} \pm 0.1$ & $3.14 \mathrm{c} \pm 1.1$ & $0.75 \mathrm{~d} \pm 0.1$ \\
\hline $\mathrm{T}_{1}$ & $1.6 b c \pm 0.1$ & $77 \mathrm{a} \pm 7$ & $5.6 \mathrm{a} \pm 1.5$ & $174 a \pm 65$ & $1.34 \mathrm{a} \pm 0.3$ & $811 \mathrm{c} \pm 09$ & $18.1 \mathrm{c} \pm 0.2$ & $2.5 \mathrm{a} \pm 0.2$ & $4.81 \mathrm{a} \pm 0.9$ & $1.45 c \pm 0.1$ \\
\hline $\mathrm{T}_{2}$ & $1.4 \mathrm{~cd} \pm 0.2$ & $71 \mathrm{a} \pm 9$ & $5.6 \mathrm{a} \pm 1.5$ & $143 a \pm 30$ & $1.26 \mathrm{a} \pm 0.4$ & $928 b \pm 16$ & $21.9 \mathrm{ab} \pm 1.2$ & $2.6 \mathrm{a} \pm 0.2$ & $3.93 b \pm 1.6$ & $1.78 \mathrm{ab} \pm 0.1$ \\
\hline $\mathrm{T}_{3}$ & $1.5 \mathrm{c} \pm 0.1$ & $74 \mathrm{a} \pm 9$ & $5.7 \mathrm{a} \pm 0.9$ & $166 \mathrm{a} \pm 34$ & $1.01 \mathrm{a} \pm 0.4$ & $1039 a \pm 32$ & $23.0 \mathrm{a} \pm 2.2$ & $2.3 \mathrm{a} \pm 0.3$ & $3.11 \mathrm{~b} \pm 1.1$ & $1.83 a \pm 0.2$ \\
\hline $\mathrm{T}_{4}$ & $1.8 \mathrm{a} \pm 0.2$ & $75 \mathrm{a} \pm 2$ & $4.4 \mathrm{a} \pm 0.9$ & $151 \mathrm{a} \pm 29$ & $1.21 \mathrm{a} \pm 0.4$ & $939 b \pm 15$ & $20.7 b \pm 1.5$ & $2.4 \mathrm{a} \pm 0.2$ & $2.98 \mathrm{~b} \pm 0.2$ & $1.65 b \pm 0.1$ \\
\hline $\mathrm{T}_{5}$ & $1.8 \mathrm{a} \pm 0.3$ & $76 a \pm 2$ & $5.7 \mathrm{a} \pm 1.4$ & $126 \mathrm{a} \pm 51$ & $0.87 \mathrm{a} \pm 0.3$ & $784 \mathrm{c} \pm 20$ & $17.4 \mathrm{c} \pm 0.6$ & $2.5 \mathrm{a} \pm 0.2$ & $3.18 b \pm 0.9$ & $1.38 \mathrm{c} \pm 0.1$ \\
\hline $\mathrm{T}_{6}$ & $1.5 \mathrm{c} \pm 0.1$ & $75 a \pm 7$ & $5.7 \mathrm{a} \pm 1.4$ & $172 \mathrm{a} \pm 46$ & $0.95 \mathrm{a} \pm 0.6$ & $1017 \mathrm{a} \pm 503$ & $22.5 \mathrm{ab} \pm 1.3$ & $2.3 \mathrm{a} \pm 0.2$ & $2.73 b \pm 0.4$ & $1.80 \mathrm{ab} \pm 0.1$ \\
\hline $\mathrm{T}_{7}$ & $1.3 \mathrm{~d} \pm 0.0$ & $60 \mathrm{~b} \pm 6$ & $5.9 \mathrm{a} \pm 0.5$ & $156 a \pm 53$ & $1.26 \mathrm{a} \pm 0.6$ & $810 c \pm 104$ & $17.2 \mathrm{c} \pm 1.8$ & $2.3 \mathrm{a} \pm 0.2$ & $3.14 b \pm 0.7$ & $1.38 \mathrm{c} \pm 0.2$ \\
\hline
\end{tabular}

the NPK treatment seemed to have the greatest impact on the yield and growth parameters of sorghum except for leaf area, leaf area per plant and stem diameter. In general, the Butana sorghum gave higher grain and dry matter yield than that of Arfa Gadmak variety in both seasons.

In the sec season, the stem diameter of Arfa Gadmak was significantly $(P \leq 0.01)$ higher than Butana by $19 \%$. Incorporation of composted CM supplemented with NPK produced the highest diameter and similar to NPK application. In both seasons, stem height of both varieties followed generally similar trend to compost application. However, the application of either sole compost from CM or supported with NPK produced the longest stem height whereas in most sources of compost, Butana was 1.2 times that of Arfa Gadmak. In both seasons and varieties, the NL/PT was not different and also not affected by compost application. Incorporation of composted $\mathrm{CM}$ alone or supported with NPK has significantly $(P \leq 0.05)$ LA over the control by 47\% (in Butana) and 25\% (in Arfa Gadmak). Similar to NL/PT, main effects of compost in LA showed that Butana was 1.2 folds higher than that of Arfa Gadmak. In both seasons, LAI of Arfa Gadmak was not significantly affected by application of compost. However, compost from $\mathrm{CM}$ or mixed with $\mathrm{FM}$ has significantly $(P \leq 0.01)$ 
increased LAI from $0.45-0.7$ (in the control) or $0.3-1.11$ (in the NPK) to $0.7-1.48$. Generally, the NS/P found in Butana was significantly higher than Arfa Gadmak by $2-43 \%$. In the first season, irrespective of compost source, NS/P of Butana was significantly $(P \leq 0.01)$ increased over the control by $21-62 \%$ where compost from $\mathrm{CM}$ resulted in the highest NS/P. Similar results for Butana were also recorded in the sec season where NSP/P of plots supplied with compost was 1.7-2.1 times that found in control plots where composted plots from CM recorded the highest values. As for Arfa Gadmak, in the first season, only compost sources from FM and CM have significantly $(P \leq 0.01)$ increased NS/P over the control by $31-56 \%$ and also application of compost from $\mathrm{CM}$ produced the highest NS/P. However, in the sec season, all sources of compost have significant $(P \leq$ $0.01)$ NS/P by 58-103\%. Regardless of season and variety, incorporation of compost from all sources resulted in significant $(P \leq 0.01)$ increases in SW/P over no application. In the first season, augmenting FM or CM compost with NPK or sole CM compost has resulted in SW/P in Butana of 2.7 times that found in control treatments but similar to plots received NPK. Similarly, results of the sec season of Butana showed 2-4 times SW/P from plots with composts compared to the control and also revealed the superiority of compost from CM. As for Arfa Gadmak variety, in the first and sec seasons, plots with compost have significant $(P \leq$ 0.01 ) 1.3-2.0 and 1.8-2.4 times of SW/P that of control plots with $\mathrm{CM}$ compost recorded the highest values. Regardless of variety or season, all types of compost induced significant $(P \leq 0.01)$ increase in DMY. In the first season, an increase of $39-53 \%$ and $36 \%$ over control plots were found in varieties of Butana and Arfa Gadmak, respectively. Whereas corresponding increased values in the sec season were $17-44 \%$ and 1.3-2.1. However, adding NPK to the combined FM/CM produced similar DMY to NPK addition. Main effects of grain yield (GY) of the two varieties were found to be almost similar in both seasons. Additionally, GY of both varieties in the sec season was 2.9 times that of the first season. However, in the first season, the general trend of increase in GY was in the order of NPK $=\mathrm{CM}$ with $\mathrm{NPK}=\mathrm{CM}=\mathrm{FM}$ with $\mathrm{NPK}>\mathrm{FM} / \mathrm{CM}$ with NPK $=$ FM $>$ Control. The study revealed that, in both seasons and varieties, application of sole composted CM or supported with NPK reported the highest GY values. Accordingly, GY for Butana and Arfa Gadmak were 2.62.8 and 2.8-3.1 times the control, respectively (in the first season) and 1.8-2.0 and 2.4-2.4 times the control, respectively (in the sec season).

\section{Effects of compost application on soil properties}

With the exception of TN, differences in topsoil properties measured after harvest of the sec season between plots received composts and the control were significant (Table 6). Cultivation of sandy soils with or without compost has decreased $\mathrm{pH}$ by 0.09 to 0.16 units. Application of composted CM or combined with FYW was found to induce the maximum reduction $(2.6 \%)$. Almost, all sources of compost increased EC over the control with the highest increase $(50 \%)$ was found in plot with compost from sole CM. An increase of 47 and $53 \%$ over the control was found in treatments with composted FM and combined FM with $\mathrm{CM}$, respectively. In general, application of compost has increased available $\mathrm{P}$ in the topsoil compared to control treatment. The content of $\mathrm{P}$ in treatments with compost from FM and CM were 1.3 and 1.4 times that found in the NPK treatment, respectively. Similarly, available $\mathrm{K}^{+}$showed the superiority of FY and combined FM with $\mathrm{CM}$ where content was found to 1.7 times that determined in the NPK treatment. Irrespective of compost source, moisture content in composted plots was 56-98\% higher than control plots. The highest moisture values were determined in plots with FM, CM and mixture of FM and CM. Compared to the control, the decrease in bulk density due to application of compost varied from 4 to $6 \%$. Effects of compost application on particle size distribution were erratic and did not follow a consistent pattern. Plots received compost from FM and $\mathrm{CM}$ were found to retain significant $(P \leq 0.01)$ content of silt and clay as compared to control plots.

\section{Discussion}

This study indicates that application of composted manures on sandy soil had an acidifying effect. Soil $\mathrm{pH}$ normally decreases following the addition of organic amendments (Bulluck et al. 2002). Organic amendments may have little effect on soil $\mathrm{pH}$ and this reflects the importance of the variations in quality or initial chemical composition of the decomposing material (Melero et al. 2007). The decrease in soil $\mathrm{pH}$ after application of treatments reported in this study could possibly be due to two factors, first, nitrification of $\mathrm{NH}_{4}-\mathrm{N}$ or release of $\mathrm{H}^{+}$ions during the mineralization process (Antolin et al. 2005) and sec, to the production of some organic acids and production of $\mathrm{CO}_{2}$ as the results of the oxidation of soil organic matter by heterotrophic microorganisms and from root respiration, which may affect soil pH (Mahmoud et al. 2007). In a study conducted by Mullins and Benefeldt (2002) reported that poultry litter contains considerable amount of organic matter, hence have an impact on soil $\mathrm{pH}$ and liming due to varying amount of calcium carbonate in poultry feed. The increase in soil organic $\mathrm{C}$ reported here could be possibly attributed to the continuous addition of $\mathrm{C}$ through compost (Blanco-canqui and Lal 2007; Bhattacharyya et al. 2008). The increase in OC found here is in line with Ibrahim and Fadni (2012) who reported an increase in soil moisture content of sandy soils in Kordofan State, Sudan of $88 \%$ in plots treated with two seasons of chicken and cattle manure over control plots. Furthermore, two successive seasons of application of various composts (cattle feedlot, manures from poultry, chicken, camel and sewage sludge) in a sandy soil showed increment of OC despite marked differences in quality and 
Ahmed et al. / Intl J Agric Biol, Vol 23, No 2, 2020

Table 6: Effects of organic composts and NPK application alone and in combinations on some selected physico-chemical properties of topsoil after the $2^{\text {nd }}$ season (Average \pm standard deviation, $n=4$ )

\begin{tabular}{|c|c|c|c|c|c|c|c|c|c|c|c|}
\hline \multirow{2}{*}{\multicolumn{2}{|c|}{ Treat $\mathrm{pH}_{\text {(paste) }}$}} & $\mathrm{ECe}$ & $\mathrm{OC}$ & $\mathrm{TN}$ & $\mathrm{P}$ & $\mathrm{K}$ & Silt & Clay & Sand & $\mathrm{MC}$ & \multirow{2}{*}{$\begin{array}{l}\mathrm{Bd} \\
\mathrm{gcc}^{-3}\end{array}$} \\
\hline & & $\left(\mathrm{dSm}^{-1}\right)$ & \multicolumn{2}{|c|}{$\mathrm{gkg}^{-1}$} & \multicolumn{2}{|c|}{$\mu \mathrm{gg}^{-1}$} & \multicolumn{4}{|c|}{$\mathrm{gkg}^{-1}$} & \\
\hline $\mathrm{T}_{0}$ & $6.82 \mathrm{a}^{* *} \pm 0.02$ & $0.16 \mathrm{ed} \pm 0.01$ & $1.7 \mathrm{e} \pm 0.1$ & $0.1 \mathrm{a} \pm 0.0$ & $2.44 d \pm 0.2$ & $2.73 f \pm 0.1$ & $70 c \pm 1$ & $27 b c \pm 4$ & $903 a \pm 3$ & $46.7 f \pm 5$ & $1.44 \mathrm{a} * \pm 0.02$ \\
\hline $\mathrm{T}_{1}$ & $6.73 c \pm 0.02$ & $0.21 b \pm 0.02$ & $2.5 \mathrm{ab} \pm 0.4$ & $0.2 \mathrm{a} \pm 0.0$ & $4.61 \mathrm{a} \pm 0.4$ & $5.58 \mathrm{~b} \pm 0.5$ & $71 \mathrm{c} \pm 2$ & $28 \mathrm{~b} \pm 2$ & $908 \mathrm{a}^{* *} \pm 7$ & $92.6 \mathrm{a} * * \pm 3$ & $1.35 \mathrm{~d} \pm 0.02$ \\
\hline $\mathrm{T}_{2}$ & $6.78 b \pm 0.02$ & $0.19 b c \pm 0.02$ & $1.9 \mathrm{cde} \pm 0.1$ & $0.1 \mathrm{a} \pm 0.0$ & $3.64 b \pm 0.1$ & $4.21 \mathrm{~d} \pm 0.2$ & $71 c \pm 3$ & $27 b \pm 3$ & $902 \mathrm{a} \pm 3$ & $80.0 \mathrm{c} \pm 1$ & $1.41 \mathrm{ab} \pm 0.05$ \\
\hline $\mathrm{T}_{3}$ & $6.64 \mathrm{e} \pm 0.01$ & $0.24 \mathrm{a}^{* *} \pm 0.01$ & $2.2 \mathrm{abc} \pm 0.3$ & $0.3 a \pm 0.1$ & $5.00 \mathrm{a} * * \pm 0.1$ & $6.14 a \pm 0.2$ & $70 c \pm 3$ & $27 b c \pm 5$ & $903 a \pm 4$ & $88.4 a b \pm 3$ & $1.35 d \pm 0.02$ \\
\hline $\mathrm{T}_{4}$ & $6.68 \mathrm{~d} \pm 0.02$ & $0.20 b \pm 0.01$ & $1.8 \mathrm{de} \pm 0.2$ & $0.2 \mathrm{a} \pm 0.0$ & $4.81 \mathrm{a} \pm 0.2$ & $5.07 \mathrm{c} \pm 0.5$ & $76 a b \pm 2$ & $21 c \pm 1$ & $903 a \pm 6$ & $72.6 \mathrm{~d} \pm 1$ & $1.37 \mathrm{~cd} \pm 0.02$ \\
\hline $\mathrm{T}_{5}$ & $6.77 \mathrm{~b} \pm 0.02$ & $0.15 \mathrm{e} \pm 0.02$ & $1.9 \mathrm{cde} \pm 0.2$ & $0.2 \mathrm{a} \pm 0.0$ & $3.49 b c \pm 0.2$ & $3.64 \mathrm{e} \pm 0.1$ & $77 b \pm 1$ & $37 a^{* *} \pm 6$ & $5886 c \pm 6$ & $53.8 \mathrm{e} \pm 2$ & $1.39 b c \pm 0.01$ \\
\hline $\mathrm{T}_{6}$ & $6.66 \mathrm{ed} \pm 0.03$ & $0.20 \mathrm{~b} \pm 0.01$ & 2. $\mathrm{a}^{* *} 6 \pm 0.3$ & $0.2 \mathrm{a} \pm 0.0$ & $3.51 b \pm 0.3$ & $6.24 \mathrm{a} * * \pm 0.1$ & $82 a^{* *} \pm 3$ & $30 a \pm 2$ & $888 b c \pm 5$ & $88.9 a \pm 2$ & $1.36 \mathrm{~cd} \pm 0.01$ \\
\hline $\mathrm{T}_{7}$ & $6.68 \mathrm{~d} \pm 0.03$ & $0.18 \mathrm{~cd} \pm 0.01$ & $2.1 \mathrm{bcd} \pm 0.3$ & $0.2 \mathrm{a} \pm 0.0$ & $3.10 c \pm 0.1$ & $5.33 b c \pm 0.1$ & $78 a b \pm 1$ & $28 \mathrm{~b} \pm 3$ & $894 b \pm 3$ & $83.7 b c \pm 4$ & $1.38 \mathrm{~cd} \pm 0.01$ \\
\hline
\end{tabular}

quantity of organic matter inputs (Castána et al. 2016; Dawi et al. 2017). The improvement in the content of soluble elements is expected and would possibly be due to the load found in the composts. Additionally, application of organic materials provides extra functional groups in fulvic acid, carboxyl groups and phenolic-OH which may increase nutrients adsorption affinity (Eshwar et al. 2017; Rajashekhar et al. 2017). The highest content of $\mathrm{P}$ and $\mathrm{K}^{+}$ were obtained at $\mathrm{CM}$ and $\mathrm{FM} / \mathrm{CM}$ treatments. High content of $\mathrm{P}$ and $\mathrm{K}^{+}$in $\mathrm{CM}$ and $\mathrm{FM} / \mathrm{CM}$ treatments is supported by the findings reported by Herencia et al. (2007) and Suge et al. (2011) who found that the use of organic fertilizer resulted in higher soil organic matter, soil $\mathrm{N}$ content and available $\mathrm{P}$ and $\mathrm{K}^{+}$. This indicates improvement in soil fertility with added compost a result that is consistent with findings of various previous studies using poultry manure (Kingery et al. 1993; Adenawoola and Adejoro 2005). High percolation of water in sandy soils is mainly attributed to poor physical properties. The positive effects of composted manure on soil water content and the reduction of bulk density in our study could possibly be attributed to the buildup of soil organic matter which in turn improves the soil water holding capacity through decreasing bulk density and thus increasing pore volume, improvement of aggregation and structure and additional surface area (Franzluebbers 2002). Improvement in physical quality of sandy soils treated with cattle manure was attributed to significant effects on total porosity, bulk density, drainable pores, water holding capacity and available water (El-Nagar and Mohamed 2019). Although, Minasny and McBratney (2018) showed that increasing organic $\mathrm{C}$ has small effect on soil water content, but the increase was larger in sandy soils. This was earlier supported that the sensitivity of water retention to changes in organic matter content was highest in sandy soils (Rawls et al. 2003). Under similar conditions to our study, successive application of composts improved soil physical properties (Agbede et al. 2008) and increased water retention capacity due to increased pore volumes and reduced bulk density (Shashoug et al. 2017).

In the present study, application of composts showed improvement in growth parameters of sorghum which may possibly be attributed to improvement in the quality of sandy soils including nutrient adsorption and availability, water retention and microbial activities (Wendimu 2016). Results of growth and yield parameters reported in this study indicated that both sorghum varieties had in general similar responses to compost application and showed no significant superiority of each variety. The two varieties are described as short maturing in the rain-fed area and could therefore justify clear absence of superiority. Better growth performance of sorghum under rain fed conditions with added manure was previously documented (Elbasri et al. 2011; Elkarim 2012). Later authors have postulated that increase in soil moisture content have accelerated cell divisions and that may consequently result in thick and elongated stems. Meta-analysis proved that the overall effect of application of organic amendments was significant only when added to marginal soils of low fertility, sandy texture and under tropical climate (Chen et al. 2018). Ismaeil et al. (2012) found that increased application rate of chicken manure to sandy soils increased plant height, stem diameter, number of leaves per plant and leaf area index of forage sorghum. Increased grain and dry matter yield and yield parameters with added compost of this study indicate superiority of compost from chicken manure or integrated application of compost with NPK. Due to high organic matter, exchangeable cations, cation exchange capacity and base saturation, chicken manure is considered one of the best sources of organic fertilizers that has been reported to increase yield by 1.8 folds that of conventional fertilizers (Yaldiz et al. 2019). Enhanced soil fertility and additional nutrients in the compost (Table 3) could possibly be the reasons behind improved sorghum yield. Under the prevailing environmental conditions of our study, Elkerim (2012) found that higher grain yield and yield components of sorghum with application of $15 \mathrm{t} \mathrm{ha}^{-1}$ of compost from farm yard manure. Application of compost in an irrigated sandy loam soils with increased irrigation cycle resulted in similar sorghum yield to recommended irrigation cycle (Shashoug et al. 2017). Similarly, due to higher quantity of macro and micronutrients added to the soil in the form of farm yard manure, an increase of $24 \%$ in grain yield of millet was reported (Ullasa et al. 2017). Overall findings showed that in biophysically stressed aridisol, the practice 
of application of nutrients using organic sources improved the soil quality indices as well.

\section{Conclusion}

Land application of composts with and without inorganic fertilizer significantly improved the grain and dry matter yield of the two sorghum varieties. Incorporation of farm manure compost with NPK had the largest increase in grain yield parameters compared to all other treatments. Incorporation of organic composts along with NPK in sandy soils significantly reduced $\mathrm{pH}$ and soil bulk density and enhanced organic carbon, soluble $\mathrm{P}$ and $\mathrm{K}$, and soil moisture retention.

\section{References}

Adenawoola AR, SA Adejoro (2005). Residual effects of poultry manure and NPK fertilizer residues on soil nutrient and performance of jute (Corchorus olitorius L.). Nig J Soil Sci15:133-135

Agbede TM, SO Ojeniyi, AJ Adeyemo (2008). Effect of poultry manure on soil physical and chemical properties, growth and grain yield of sorghum in southwest, Nigeria. Amer-Eur J Sustain Agric 2:72-77

Antolin MC, I Pascual, C García, A Polo, M Sánchez-Díaz (2005). Growth, yield and solute content of barley in soils treated with sewage sludge under semiarid Mediterranean conditions. Field Crops Res 94:224 237

AOAC (1984). Official Methods of Analysis. Association of Official Analytical Chemists, $14^{\text {th }}$ edn. A.O.A.C., Arlington

Asomaning SK, MK Abekoe, GNN Dowuona, OK Borggaard, JA Kristensen, H Breuning (2015). Sustainable long-term intensive application of manure to sandy soils without phosphorus leaching: a case study from Ghana. Acta Agric Scand Sect B Soil Plant Sci 65:747-754

Bhattacharyya P, S Kundu, V Prakash, HS Gupta (2008). Sustainability under combined application of mineral and organic fertilizers in a rain fed soybean-wheat system of the Indian Himalayas. Eur J Agron 28:33-46

Blanco-Canqui H, R Lal (2007). Soil structure and organic carbon relationships following 10 years of wheat straw management in notill. Soil Till Res 95:240-254

Bulluck LR, M Brosius, GK Evanlyo, JB Ristaino (2002). Organic and synthetic fertility amendments influence soil microbial, physical and chemical properties on organic and congenital farms. Appl Soil Ecol 19:147-160

Castána E, P Sattia, M González-Poloa, MCI María, MJ Mazzarino (2016). Managing the value of composts as organic amendments and fertilizers in sandy soils. Agric Ecosyst Environ 224:29-38

Chen Y, M Camps-Arbestain, Q Shen, B Singh, ML Cayuelahe (2018). Long-term role of organic amendments in building soil nutrient fertility: a meta-analysis and review. Nutr Cycl Agroecosyst 111:103-125

Chesworth W (2008). Encyclopaedia of soil science. Springer Science and Business Media, Dordrecht, The Netherlands

Dawi BSI, AR Mubarak, Y Norikazu, AMA Eltilib, AA Elhadi, FAM Rezig (2017). Use of three Organic Amendments for Improvement of Desert Soil Properties and Cultivation of Grain Sorghum (Sorghum bicolor L.). Sudan J Desert Res 9:108-141

Elbasri M, AM El Naim, BE Ebeadallah, KA Ibrahim (2011). Effect of tillage and farm yard manure on yield and yields components of grain sorghum (Sorghum bicolor L. Monech) in rain-fed. Intl J Curr Res 3:389-392

Elkarim IAIF (2012). Integrated Effect of Tillage and Manure on Sorghum (Sorghum Bicolor L. Moench) Growth and Yield in Gardud Soils of North Kordofan State. Ph.D. Thesis. Faculty of Agriculture, University of Khartoum, Sudan
El-Nagar DA, RAA Mohamed (2019). Characterization and impact of cattle manure particle size on physical properties of sandy soils. $J$ Geosci Environ Prot 7:180-194

Eshwar M, M Srilatha, KB Rekha, SHK Sharma (2017). Characterization of Humic Substances by Functional Groups and Spectroscopic Methods. Intl J Curr Microbiol Appl Sci 6:1768-1774

FAO (2018). F.A.O. Crop and Food Supply Assessment Missions to the Sudan. Rome, Italy

FAO (2009). Preliminary 2009 Data on Sorghum Area, Production and Productivity. FAO, Rome, Italy

FAO (2001). Lecture Notes on the Major Soils of the World. World Soil Research Report. F.A.O., Rome, Italy

FAO (1980). Food and Agriculture Organization of the United Nations. In: On-Farm Composting Methods. Misra RV, RN Roy FAO, Rome, Italy

Franzluebbers A (2002). Water infiltration and soil structure related to organic matter and its stratification with depth. Soil Till Res 66:197205

Herencia JF, JC Ruiz-Porras, S Melero, PA Garcia-Galavis, E Morillo, C Maqueda (2007). Comparison between organic and mineral fertilization for soil fertility levels, crop macronutrient concentrations and yield. Agron J 99:973-983

Ibrahim HMK, OAS Fadni (2012). Effect of organic fertilizers application on growth, yield and quality of tomatoes in North Kordofan (sandy soil) western Sudan. Green J Agric Sci 3:299-304

Ismaeil FM, AO Abusuwar, AM El Naim (2012). Influence of chicken manure on growth and yield of forage sorghum (Sorghum Bicolor $\mathrm{L}$. Moench). Intl J Agric For 2:56-60

Kakani VG, JC Vu, LHJ Allen, KJ Boote (2011). Leaf photosynthesis and carbohydrates of $\mathrm{CO}_{2}$-enriched maize and grain sorghum exposed to a short period of soil water deficit during vegetative development. $J$ Plant Physiol 168:2169-2176

Kingery WL, CW Wood, DP Delaney (1993). Impact of long-term application of broiler litter on environmentally related soil properties. J Environ Qual 23:139-147

Mahmoud E, NA EL- Kaderi, A Elbaroudi, AR Lamyaa (2007). Residual effects of different organic and inorganic fertilizers on spinach (Spiacia oleracea L.) plant grown on clay and sandy soils. J Agric Environ Sci Alex Univ Egypt 6:49-65

Mclean EO (1982). Soil pH and lime requirement. In: Methods of Soil Analysis, Part 2 Chemical and Microbiological Properties, pp: 199223. Page AL, RH Miller, DR Keeney (Eds.). American Society of Agronomy and Soil Science Society of America, Madison, Wisconsin, USA

Melero I, E Madejon, JC Ruiz, JF Herencia (2007). Chemical and biochemical properties of a clay soil under dry land agriculture system as affected organic fertilization. Eur J Agron 26:327-334

Minasny B, AB McBratney (2018). Limited effect of organic matter on soil available water capacity. Eur J Soil Sci 69:39-69

Mubarak AA, MMA Ballah (2015). Utilization of Composted Bagasse, Water Hyacinth and Banana Waste in Reclamation of Desert Soils. Drylands Coordination Group, DCG Report No. 76, Norway

Mullins LG, ES Benefeldt (2002). Poultry Litter as Soil Amendment, Crop and Soil Environmental Science, pp: 423-534. Association extension agent agricultural and natural resources, Virginia Tech Publication number, Virginia, USA

Mundia CW, S Secchi, K Akmani, G Wang (2019). A Regional comparison of factors affecting global sorghum production: The case of North America, Asia and Africa's Sahel. Sustainability 11:1-18

Nelson DW, LE Sommers (1982). Total carbon, organic carbon and organic matter In: Methods of Soil Analysis Part 2 Chemical and Microbiological Properties, pp: 539-575. Page AL, RH Miller, DR Keeney (Eds.). American Society of Agronomy and Soil Science Society of America, Madison, Wisconsin, USA

Ogbaga CC, P Stepien, GN Johnson (2014). Sorghum (Sorghum bicolor) varieties adopt strongly contrasting strategies in response to drought. Physiol Plantarum 152:389-401

Osman AK, FM Elhag, MA Mekki, EA Abdalla, JB Aune (2012). Eco-farm Research Project: Kordofan Region, Sudan. Drylands Cordination Group Report No. 71, Norway 
Ozores-Hampton M, PA Stansty, TP Salame (2011). Soil chemical, physical, and biological properties of a sandy soil subjected to longterm organic amendments. J Sustain Agric 35:243-259

Rajashekhar D, M Srilatha, RP Chandrasekhar, SSH Kumar, KB Rekha (2017). Functional and spectral characterization of humic fractions obtained from organic manures. Intl J Pure Appl Biosci 5:1254-1259

Rawls WJ, YA Pachepsky, JC Ritchie, TM Sobecki, H Bloodworth 2003. Effect of soilorganic carbon on soil waterretention. Geoderma 116:61-76

Rehim A, M Hussain, S Ahmad, S Noreen, H Dogan, M Zia-ul-Haq, S Ahmad (2016). Band application of phosphorus with farm manure improves phosphorus use efficiency, productivity and net returns of wheat on sandy clay loam soil. Turk J Agric For 40:319-326

Rezig FAM, EA Elhadi, AR Mubarak (2013). Impact of organic wastes and mineral fertilizer application on soil-crop system I: Yield and nutrients content. Arch Agron Soil Sci 59:1229-1243

SAS (1999). Institute Inc. S.A.S./STAT User's Guide, Version 8, SAS Institute Inc., Cary, North Carolina, USA

Shashoug MSA, AA Mubarak, EA Elhadi, FAM Rezig (2017). Response of fodder sorghum (Sorghum bicolor (L.) to sewage sludge treatment andirrigationintervalsina dryland condition. Euras JSoil Sci 6:144-153
Suge JK, ME Omunyin, EN Omami (2011). Effect of organic and inorganic sources of fertilizer on growth, yield and fruit quality of eggplant (Solanum Melongena L). Arch Appl Sci Res 3:470479

Ullasa M, S Pradeep, CD Shrikantha, S Sridhara, Ganapathi (2017). Effect of different organic nutrient management practices on growth, yield and economics of finger millet, Eleusine coracaca (L.) Gaertn. Intl J Farm Sci 7:10-14

Walkley A, IA Black (1934). An examination of the degtjareff method for determining soil organic matter and a proposed modification of the chromic acid titration method. Soil Sci 37:29-38

Warren A (1970). Dune trends and their implications in the Central Sudan. Zeitsch Geomorphol 10:154-180

Wendimu M (2016). Effect of farm yard manure application rate on yield and yield components of lettuce (Lactuca sative) at Jimma Southwestern Ethiopia. Intl J Res-Granth 4:75-83

Yaldız G, M Çamlıca, F Özen, SA Eratalar (2019). Effect of Poultry Manure on Yield and Nutrient Composition of Sweet Basil (Ocimum basilicum L.). Commun Soil Sci Plant Anal 50:838852 